\title{
Surgical Treatment Modalities of Carotid Artery Stenosis (Review)
}

\author{
DOI: $10.17691 / \mathrm{stm} 2015.7 .4 .25$
}

Received January 14, 2015

A.V. Yarikov, Neurosurgeon';

A.V. Balyabin, MD, PhD, Researcher'; Neurosurgeon';

K.S. Yashin, PhD Student²;

A.S. Mukhin, MD, DSc, Professor, Head of the Surgery Department, Postgraduate Faculty ${ }^{3}$

\begin{abstract}
${ }^{1}$ City Clinical Hospital No.39, 144 Moskovskoe Shosse, Nizhny Novgorod, 603028, Russian Federation; ${ }^{2}$ Privolzhsky Federal Research Medical Center, Ministry of Health of the Russian Federation, 18 Verkhne-Volzhskaya naberezhnaya St., Nizhny Novgorod, 603155, Russian Federation; ${ }^{3}$ Nizhny Novgorod State Medical Academy, 10/1 Minin and Pozharsky Square, Nizhny Novgorod, 603005, Russian Federation
\end{abstract}

The review presents the comparative analysis of current surgical techniques to treat atherosclerotic carotid lesions: carotid stenting and carotid endarterectomy (classical and everting), and describes the advantages and disadvantages of these methods introducing indications and contraindications. Particular emphasis is given to the technique and time to complete carotid endarterectomy. The paper concerns the benefits of a patch over a primary suture, as well as presents the requirements for a patch used in carotid endarterectomy. The authors studied all current materials used for patches, and gave merits and demerits of each material described. The review assesses the feasibility and safety of the more invasive surgical approach for brain revascularization in an acute period of ischemic stroke in strict compliance with surgical indications. The authors have concluded that carotid endarterectomy has a positive effect on cognitive functions in patients in the form of neurological and neuropsychological status improvement. There has been also proved that all above mentioned techniques have no advantages, moreover, they can be mutually complementary and, actually, used in chronic cerebral ischemia treatment.

Key words: carotid endarterectomy; carotid stenting; ischemic stroke; carotid artery stenosis.

Acute cerebrovascular accident (CVA) remains a major medical and social problem of our time. About 500 thousand new cases of ischemic stroke (IS) are recorded every year, and over 1 million people who have had stroke live in Russia [1-3]. The incidence of IS in the Russian Federation is 3.48 per 1,000 population a year, among the Caucasians ethnicity in the US this figure is 1.38-1.67 per 1,000 population, while in Northern and Central Europe it is $0.38-0.47$ per 1,000 population, which is one of the lowest $[4,5]$. CVA is an important factor for invalidization of the working population: only $8 \%$ of stroke survivors can return to previous work [2, $6,7]$. Out of the total mortality in Russia, CVA is $21.4 \%$ [8], and in the industrialized countries it is the third leading cause of death $[9,10]$. At the same time, despite the often poor results, the treatment and rehabilitation costs are constantly going up and currently range from $\$ 16.5$ to 22 billion per year [8]. The present situation promotes the development of preventive measures for the correction of risk factors and the development of methods of preventive medicine in CVA treatment.

The leading pathogenetic mechanism in the development of ischemic CVA is atherothrombosis, it being $57 \%[11,12]$. The idea of the link between atherosclerosis and CVA development appeared in the late XIX century. In 1875 Gowers described blindness in the left eye and right-sided hemiplegia in a patient with the occlusion of the left internal carotid artery (ICA). In 1914 Hunt suggested that ICA atherosclerosis may be a source of microemboli, causing transient ischemic attacks (TIA) [13]. This was followed by repeated attempts of surgical interventions on the carotid artery to prevent CVA. Only in 1951 Eascost reported the first successful experience of surgery on the carotid arteries. In 1953 DeBakey made the first classical carotid endarterectomy (CEE) to prevent CVA. However, the further analysis of the immediate and long-term outcomes of the surgical treatment demonstrated that some patients developed CVA despite performed CEE. It called into question the effectiveness of the surgery. In 1959 DeBakey suggested the idea of eversion CEE. This procedure included cutting off the common carotid artery (CCA), performing eversion of the primary departments of the external carotid artery (ECA) and ICA. Then Chevalier modified the eversion CEE technique. He suggested performing the intersection of the ICA more distally from

For contacts: Yarikov Anton Viktorovich, e-mail: anton-yarikov@mail.ru 
the end of the atherosclerotic plaque and longitudinal CCA arteriotomy with the following eversion of the ICA proximal portion [14]. However, this technique was not very popular, as the control of the distance of the plaque distal end was practically impossible [15]. The eversion CEE technique familiar to a modern surgeon was described by Raithel and Kasprazak in 1989. During the surgery, the ICA was cut off at the mouth followed by eversion and reanastomosis at the same mouth after plaque removal [16]. Later the two techniques - classical and eversion CEE - were repeatedly compared with each other.

The implementation of interventional radiology into vascular surgery has opened a new era in the treatment of atherosclerotic lesions of the carotid arteries. The first stenting of ICA with atherosclerotic lesion was made in 1989 [17]. Since then endovascular treatment considerably improved (new stents, embolic protection devices and other aids have been developed) with the following improvement of treatment results and outcomes. The techniques of open and endovascular intervention have also been repeatedly compared with each other in the trials at different levels, but until now the method of choice for surgical treatment of carotid stenosis is under discussion.

The National guidelines for the management of patients with diseases of brachiocephalic arteries (2013) [14] contain the following indications for surgical treatment of carotid arteries with atherosclerotic lesions:

1) symptomatic patients with more than $60 \%$ stenosis;

2) patients with $50-60 \%$ ICA stenosis having morphological instability of an atherosclerotic plaque (ulceration, hemorrhage into the plaque, intimal flotation, mural thrombus) in view of neurological symptoms, those of TIA or stroke within the last 6 months;

3) asymptomatic patients with $70-99 \%$ stenosis.

At present, the major methods of surgical prevention of IS are carotid endarterectomy and carotid stenting. We shall consider the advantages and disadvantages of each method.

\section{Carotid endarterectomy}

A number of multicenter randomized trials such as NASCET, ECST, ACAS have been carried out to assess the effectiveness of CEE and develop clear indications to the given intervention [2,10,18-26]. It has been demonstrated to be an effective way to prevent IS in ICA atherosclerotic stenosis. A long-term follow-up shows it to be many times more effective than conservative treatment and reduce the risk for IS development. The number of reconstructive operations on carotid arteries increases every year [2]. Thus, 13,144 operations on the carotid arteries were performed in Russia in 2013, 10,656 of them being CEE. Eversion CEE was performed in 6,809 patients $(63.9 \%)$, and classical CEE - in 3,847 patients $(36.1 \%)$ [27]. In the US, the number of such surgical interventions is an order of magnitude greater and is about 100,000 per year [28].

Currently, the main problem of classical CEE is the choice of patch material for angioplasty of the arteriotomy site. Previously, there were two equivalent techniques: primary closure of the arteriotomy or patch plasty of the arteriotomy hole. For a long time primary closure of the arteriotomy was the standard operation and satisfied the surgeons [29]. This technique is easier to perform, does not extend the time of a surgery, does not require placing a foreign matter into the operational wound and, therefore, reduces the risk for postoperative complications. However, further analysis of early postoperative outcomes demonstrated rather high complication rates (3-20\%): thrombosis, restenosis, ICA occlusion and, therefore, strokes that accompanied the given reconstruction technique [30]. Besides, restenosis at the site of the operated carotid artery can cause CVA in the immediate as well as late postoperative period [31].

To improve the immediate and late outcomes CEE, a patch plasty technique at the site of arteriotomy was suggested. Using a patch to close the arteriotomy defect demonstrated better results when compared with primary closure of arteriotomy, particularly in the long-term period [32]. The advantage of the technique has been proved in many clinical studies (Table 1).

Currently, the use of a patch for closure of the arteriotomy is a standard CEE operation [14]. A patch should meet the following requirements [28]:

durability;

strength;

lower risk for restenosis;

anticoagulant function;

low risk for infection;

easy sampling;

convenient use.

There is a wide choice of patch materials: autovein, autoartery (a portion the superior thyroid artery is commonly used), polytetrafluoroethylene (PTFE), dacron, canned dura, xenopericardium [14].

The advantage of autologous vein is that it is not a foreign material and its grafting is less expensive. The most common source of autovenous patch is a segment of the great saphenous vein. However, the place of patch sampling still remains disputable. A number of studies have shown that venous patch rupture occurs more often when sampling is performed by the ankle, therefore it is better to perform it on the hip [14]. The disadvantage of using autologous vein is a need for additional incision. Besides, sampling is impossible in a number of cases: saphenectomy in the past history, lower extremity venous disease, suppurative disease of the skin at the site of sampling, as well as a potential need for the great saphenous vein for lower extremity revascularization [42, 43].

Using an autologous artery patch can be of interest. 
Table 1

Effectiveness of two methods for carotid endarterectomy: primary closure and patch plasty of an arteriotomy zone

\begin{tabular}{|lccccccc|}
\hline \multicolumn{1}{|c}{ Studies } & \multicolumn{2}{c}{ Total number of patients } & \multicolumn{2}{c}{ Number of strokes (\%) } & \multicolumn{2}{c}{ Number of restenosis (\%) } \\
\cline { 2 - 7 } & $\begin{array}{l}\text { Primary } \\
\text { closure }\end{array}$ & Patch & $\begin{array}{c}\text { Primary } \\
\text { closure }\end{array}$ & Patch & $\begin{array}{l}\text { Primary } \\
\text { closure }\end{array}$ & Patch \\
\hline Hertzer et al., 1987 [33] & 483 & 434 & 3.1 & 0.7 & 31 & 9 \\
\hline Ranaboldo et al., 1993 [34] & 104 & 109 & 5.8 & 1.8 & 16 & 6 \\
\hline AbuRahma et al., 1996 [35] & 135 & 264 & 5.2 & 1.5 & 12 & 3 \\
\hline Katras et al., 2001 [36] & 97 & 107 & 2.8 & 1.0 & 9 & 6 \\
\hline Ali et al., 2005 [37] & 117 & 119 & 7.7 & 1.7 & 25 & 7 \\
\hline Rockman et al., 2005 [38] & 233 & 1377 & 5.6 & 2.2 & & \\
\hline Verhoeven et al., 2005 [39] & 83 & 236 & 6.0 & 2.5 & 11 & 7 \\
\hline Mannheim et al., 2005 [40] & 216 & 206 & 1.9 & 3.9 & 8.6 & 2.2 \\
\hline Hertzer, Mascha, 2006 [41] & 783 & 1479 & 2.8 & 1.4 & 29 & 15 \\
\hline
\end{tabular}

Table 2

Effectiveness of patch materials used for arteriotomy zone plasty

\begin{tabular}{|c|c|c|c|c|c|c|c|c|c|c|c|c|}
\hline \multirow[b]{2}{*}{ Studies } & \multicolumn{4}{|c|}{ Total number of patients } & \multicolumn{4}{|c|}{ Number of strokes (\%) } & \multicolumn{4}{|c|}{ Number of restenosis (\%) } \\
\hline & $\begin{array}{l}\text { 등 } \\
\text { 을 } \\
\text { 인 }\end{array}$ & $\begin{array}{l}\text { 혼 } \\
\text { ㅁ }\end{array}$ & 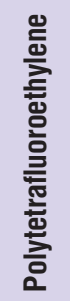 & 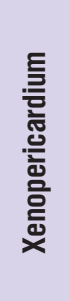 & $\begin{array}{l}\text { 등 } \\
\text { 을 }\end{array}$ & $\begin{array}{l}\text { 혼 } \\
\text { 요 }\end{array}$ & 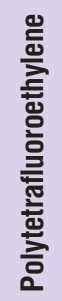 & 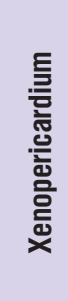 & $\begin{array}{l}\text { 듷 } \\
\text { 号 }\end{array}$ & $\begin{array}{l}\text { 혼 } \\
\text { ¿ूँ }\end{array}$ & 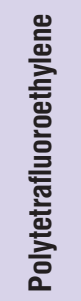 & 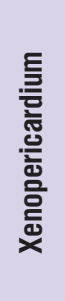 \\
\hline AbuRahma et al., 1996 [35] & 130 & & 134 & & 0.8 & & 2.2 & & 2.9 & & 2.2 & \\
\hline Archie, 2000 [45] & 903 & 359 & 27 & & & & & & 0.6 & 6.4 & 3.7 & \\
\hline Jacobowitz et al., 2001 [46] & 159 & 90 & & & 2.0 & 2.2 & & & 2.2 & 8.5 & & \\
\hline Greco et al., 2003 [47] & 80 & & 80 & & 1.3 & & 6.4 & & 9.3 & & 13.3 & \\
\hline Naylor et al., 2004 [48] & 134 & 133 & & & 4.5 & 7 & & & 1.6 & 7 & & \\
\hline AbuRahma et al., 2008 [49] & & 100 & 100 & & & 3 & 2 & & & 21 & 11 & \\
\hline Fokin, Kuvatov, 2013 [42] & 83 & & 113 & & 3.6 & & 4.5 & & 1.3 & & 10.4 & \\
\hline Karpenko et al., 2013 [50] & & & 61 & 178 & & & 0 & 1.5 & & & 31.2 & 9.8 \\
\hline
\end{tabular}

It has the same advantages as autologous vein using, but with less traumatic sampling (no additional incision). It should also be mentioned that the superior thyroid artery atherosclerosis is quite rare, indicating its availability for being a source of material [14]. Therefore, in cases when autologous vein can not be used for a number of reasons, a superior thyroid artery patch can be used. Rerkasem and Rothwell's review, that includes 13 studies and 2,083 surgeries, demonstrated a risk for restenosis and perioperative stroke to be higher in the group using synthetic materials (PTFE), and the formation of pseudoaneurysms in the group using autologous vein [44]. Thus, each material has advantages and disadvantages (Table 2).

A Cochrane Stroke Group review [51] describes 5 studies on the analysis of the results of 2,589 operations of classical and eversion CEE. Eversion CEE is claimed to be associated with a lower risk for restenosis. The number of cases with restenosis and occlusion in the groups of eversion and classical CEE were 2.5 and $5.2 \%$, respectively, with no statistically significant difference in the incidence of local and neurological complications.

Antonopoulos et al. [52] summarized the results of 8,530 eversion and 7,721 classical CEE in the meta- 
analysis which included 21 trials (7 randomized and 14 unrandmized ones). A decreased incidence of stroke in the early postoperative period (up to 30 days after surgery) and death due to stroke was recorded in the eversion CEE group. In the late postoperative period (more than 30 days after the surgery) the eversion CEE group had a decreased number of cases with occlusion and mortality. Thus, eversion CEE seems to be more preferable than classical one due to the lower incidence of complications in the early and late postoperative periods.

In 2012 the "Stroke" journal published the results of the SPACE-1 trial [53]. It compared the eversion and classical CEE techniques in patients with symptomatic carotid artery stenosis (more than $50 \%$ stenosis). It was an unrandomized study conducted in 35 medical centers. An intraluminal shunt was more frequently used in the classical CEE group (65 vs. 17\%), closure of the ateriotomy defect at classical CEE was performed with a patch. 516 patients were divided into two groups: the first group underwent eversion CEE ( $n=206,39.9 \%)$, the second group underwent classical CEE ( $n=310,60.1 \%)$. Complications and their incidence rates are shown in Tables 3 and 4.

The results of this trial suggest that the incidence of neurological complications in the early postoperative period is lower in the group of classical CEE with patch plasty repair. However, eversion CEE turned out to be more effective than classical one in the long-term prevention of stroke.

Table 3

Post-carotid endarterectomy complications in the early post-operative period (up to 30 days after surgery) (\%)

\begin{tabular}{lcc}
\hline \multicolumn{1}{c}{ Complications } & $\begin{array}{c}\text { Eversion carotid } \\
\text { endarterectomy }\end{array}$ & $\begin{array}{c}\text { Classical carotid } \\
\text { endarterectomy }\end{array}$ \\
\hline Stroke & 4 & 0.3 \\
\hline Occlusion & 0 & 0.3 \\
\hline Hematoma of the post-operative wound & 8 & 5 \\
\hline Cerebral nerve lesion & 8.2 & 8.1 \\
\hline Transient ischemic attacks & 2 & 3 \\
\hline Infected wound & 1 & 0.3 \\
\hline Headache & 2 & 3 \\
\hline
\end{tabular}

Table 4

Post-carotid endarterectomy complications in the late post-operative period (over $\mathbf{3 0}$ days after surgery) (\%)

\begin{tabular}{lcc}
\hline \multicolumn{1}{|c}{ Complications } & $\begin{array}{c}\text { Eversion carotid } \\
\text { endarterectomy }\end{array}$ & $\begin{array}{c}\text { Classical carotid } \\
\text { endarterectomy }\end{array}$ \\
\hline Stroke in the ipsilateral vascular bed & 0 & 2.9 \\
\hline Any stroke & 1 & 6.1 \\
\hline Lethality & 3.4 & 2.9 \\
\hline Any stroke + lethality & 4.4 & 9.0 \\
\hline Restenosis & 2.4 & 3.2 \\
\hline
\end{tabular}

The analysis of the trials on classical and eversion CEE allowed formulating individual indications for each of the techniques.

Indications for eversion CEE are:

a high degree of brain tolerance to ischemia [20];

local atheroma up to $1 \mathrm{~cm}[20,54]$;

combination of atherosclerosis with excessive ICA length (C- and S-shaped deformation, ICA looping) [20]. Indications for classical CEE:

low tolerance to cerebral ischemia when shunting is necessary [20];

prolonged atheroma (more than $2 \mathrm{~cm}$ ) [20];

high location of bifurcation of the CCA (at the level of C2-3) [20].

The issue of the time for CEE surgery in patients after a stroke has not been fully studied yet. The time period from IS onset to surgery on brain revascularisation remains disputable. A number of publications recommend to perform surgery on $4-6^{\text {th }}$ week after IS due to a high risk of intracerebral hemorrhage and/or increasing the ischemic area during surgery in the early stages [20, 55]. At the same time, prolonged waiting time for surgery increases the risk for repeated IS [56]. That is why some studies and recently published national and international guidelines recommend performing CEE within a shorter period of time - the first two weeks after IS debut [18, $32,56-65]$, and according to some data, the best results of surgical treatment have been given within 2-7 days from the start of the stroke symptoms [56, 62, 65-67]. CEE performed in the first days after IS is not followed by an increase in the incidence of postoperative complications, deaths, longer hospitalization, compared with later surgery $[58,63,68]$ and thus allows the quickest possible elimination of the cause of the IS pathological process, that is atherosclerosis of the carotid artery [17, 56]. This, in turn, prevents the augmentation of gross neurological deficit and reduces the risk for repeated IS, reducing treatment and rehabilitation time which significantly reduces the costs [69]. The period of up to 6 months after IS is optimal for surgery as operations performed at this time, are more favorable for the regression of neurological symptoms, improvement of clinical effect, and therefore, the quality of life $[20,58,61]$. Surgery in a later period (more than 1 year after IS) is more of preventive than therapeutic value [20].

The main factors determining the urgency of carotid revascularization in patients who have had CVA are: the lesion character of the carotid arteries, the presence (or absence) and infarct size of the brain on CT, the degree of neurological deficit, concomitant pathology. Contraindications to CEE in the immediate period after IS are impairment of consciousness and severe disabling stroke. 
This supports more active tactics in the treatment of patients in the acute period of IS in strict compliance with the indications for surgery $[57,64,69,70]$.

Patients who underwent CEE in the distant postoperative period (12 months), demonstrated improvement of neurological and neuropsychic status, cognitive, higher cortical, motor and sensory functions, the level of attention and performance and, as a consequence, the quality of life [20,71-83]. The earlier the operation for chronic cerebral ischemia is performed, the more complete the neurological deficit regression will be [20]. CEE in patients with asymptomatic carotid artery stenosis slows down chronic cerebral ischemia progression by improving neurological and/or neuropsychic status $[71,74,76,77,79,82,83]$.

Thus, CEE can be considered not only a method of preventing IS, but also a method of chronic cerebral ischemia treatment and rehabilitation $[57,61]$.

\section{Endovascular stenting of the carotid arteries}

To date, there are no definite indications and contraindications to carotid stenting (CS). It is currently regarded as an alternative method of treatment of carotid artery atherosclerosis. Stenting is a less traumatic surgical intervention than CEE. To compare the two methods of CS and CEE we analyzed the results of multicenter studies in patients with symptomatic (>50\%) and asymptomatic (>70\%) carotid artery stenosis, which allow evaluating the effectiveness of treatment outcomes and complications [84].

We used the data of surgical treatment given at the medical centers in the States of New York and California. Those were 6,360 patients with CS, 41,392 - with CEE, while 43,236 patients had asymptomatic carotid stenosis $(91 \%)$, and 4,516 had symptomatic stenosis (9\%). The CS group demonstrated a high level of comorbidity: diabetes, hyperlipidemia, hypertension, neck and kidney cancer, peripheral vascular disease. These data are presented in Table 5.

In the group of symptomatic patients lethality in combination with stroke was higher in patients having had CS than in the CEE patients ( 8.3 vs. $4.6 \%$ ), while in the group of asymptomatic patients, it was equivalent (2.4 vs. $1.9 \%$ ) after using both surgical methods [84]. This analysis showed CEE advantages in the group of symptomatic patients.

The analysis of the CREST trial $[85,86]$ showed the results of surgical treatment of 2,502 patients with symptomatic $(n=1,321)$ and asymptomatic $(n=1,181)$ stenosis. The patients were divided into two groups: the first group underwent $\mathrm{CEE}$, the second one underwent

Table 5
CS (protectors were used in $98 \%$ of cases). The study was carried out in 117 medical facilities in Canada and the United States. The follow-up period was 30 days after surgery. The results of the study are presented in Table 6.

This study demonstrated a higher risk for myocardial infarction in patients who underwent CEE, and stroke in the CS group. In patients younger than 70 years, the results were better in the CS group, while in patients over 70 - in the CEE group. The risk for cranial nerve palsy was significantly higher in the CEE group [85]. The obtained findings suggest that CS and CEE are two equally effective surgical interventions for carotid revascularization.

One more trial to compare these two methods was ICSS reported in 2010 [87]. Only patients with symptomatic carotid stenosis $(>50 \%)$ were involved in the study. 1,713 patients were divided into two groups: the first group underwent CEE $(n=855)$, the second one - CS ( $\mathrm{n}=858), 75 \%$ of cases using protectors (Table 7).

In this trial, the risk for cranial nerve palsy turned out to be higher in the CEE group. Based on these results, we can conclude that CEE is a more effective method for cerebral revascularization in patients with symptomatic

Complications during hospital staying after surgical treatment for carotid artery stenosis [84] (\%)

\begin{tabular}{lcccc}
\hline \multicolumn{1}{c}{ Complications } & \multicolumn{2}{c}{ Asymptomatic stenosis } & \multicolumn{2}{c}{ Symptomatic stenosis } \\
\cline { 2 - 5 } & $\begin{array}{c}\text { Carotid } \\
\text { stenting }\end{array}$ & $\begin{array}{c}\text { Carotid } \\
\text { endarterectomy }\end{array}$ & $\begin{array}{c}\text { Carotid } \\
\text { stenting }\end{array}$ & $\begin{array}{c}\text { Carotid } \\
\text { endarterectomy }\end{array}$ \\
\hline Lethality & 0.55 & 0.39 & 3.68 & 1.29 \\
\hline Stroke & 2.04 & 1.75 & 5.71 & 4.05 \\
\hline Respiratory complications & 1.38 & 2.44 & 1.84 & 1.29 \\
\hline Hypotension & 3.65 & 1.24 & 2.95 & 1.29 \\
\hline Transient ischemic attacks & 0.32 & 0.30 & 0.37 & 0 \\
\hline Cerebral nerve palsy & 0.18 & 0.44 & 0.18 & 0 \\
\hline
\end{tabular}

Table 6

CREST trial results $[85,86](\%)$

\begin{tabular}{lcc}
\hline \multicolumn{1}{c}{ Complications } & $\begin{array}{c}\text { Carotid } \\
\text { stenting }\end{array}$ & $\begin{array}{c}\text { Carotid } \\
\text { endarterectomy }\end{array}$ \\
\hline Myocardial infarction (asymptomatic) & 1.2 & 2.2 \\
\hline Myocardial infarction (symptomatic) & 1.0 & 2.3 \\
\hline Extensive stroke (asymptomatic) & 0.5 & 0.3 \\
\hline Extensive stroke (symptomatic) & 1.2 & 0.9 \\
\hline Minor stroke (asymptomatic) & 2.0 & 1.0 \\
\hline Minor stroke (symptomatic) & 4.3 & 2.3 \\
\hline Stroke (asymptomatic) & 2.5 & 1.4 \\
\hline Stroke (symptomatic) & 5.5 & 3.2 \\
\hline Cranial nerve leison & 0.3 & 4.7 \\
\hline
\end{tabular}


Table 7

ICSS trial results [87] (number $/ \%$ )

\begin{tabular}{lcc}
\hline \multicolumn{1}{c}{ Complications } & $\begin{array}{c}\text { Carotid } \\
\text { stenting }\end{array}$ & $\begin{array}{c}\text { Carotid } \\
\text { endarterectomy }\end{array}$ \\
\hline Stroke (within 120 days) & $65 / 7.7$ & $35 / 4.1$ \\
\hline $\begin{array}{l}\text { Complications (stroke, lethality, } \\
\text { mayocardial infarction) }\end{array}$ & $72 / 8.5$ & $44 / 5.2$ \\
\hline Lethality & $19 / 2.3$ & $7 / 0.8$ \\
\hline
\end{tabular}

Table 8

Results of classical and eversion carotid endarterectomy and carotid stenting in Russia in 2013 [27]

\begin{tabular}{lccc}
\hline \multicolumn{1}{|c}{ Indices } & $\begin{array}{c}\text { Classical carotid } \\
\text { endarterectomy }\end{array}$ & $\begin{array}{c}\text { Eversion carotid } \\
\text { endarterectomy }\end{array}$ & $\begin{array}{c}\text { Carotid } \\
\text { stenting }\end{array}$ \\
\hline Number of operations & 3.847 & 6.809 & 2.302 \\
\hline $\begin{array}{l}\text { Number of acute cerebrovascular } \\
\text { accident (\%) }\end{array}$ & 1.2 & 0.9 & 0.6 \\
\hline Lethality (\%) & 0.8 & 0.6 & 0.2 \\
\hline
\end{tabular}
Willis) [94]. tortuosity [94, 99]; [14];

on the opposite side and/or anomalies in the circle of

CS must not be performed:

in patients with a calcified atherosclerotic plaque or an extended atherosclerotic plaque (over $2 \mathrm{~cm}$ ) [14];

when stenosis is combined with abnormal ICA

in patients with an unstable atherosclerotic plaque

in patients with disseminated atherosclerotic lesions of the aorta and the brachycephalic trunk [18, 99];

in patients with ICA stenosis of over $90 \%$ [99].

Conclusion. Currently, none of the types of surgery for the carotid artery atherosclerosis demonstrated significant advantages one over the other. All methods of surgical treatment should be seen not as competing but mutually complementary.

The choice of the type of surgery for each patient should be decided

carotid stenosis. However, it should be noted that in the CREST trial for the CS group, embolic protection devices were used more often - in $98 \%$ of cases, while in the ICSS trial only in $75 \%$, and more experienced doctors performed surgery in the CREST trial [88-90] .

Currently, the CEE is an operation of choice for carotid artery stenosis, more cost-effective surgical intervention with a lower incidence of postoperative stroke and restenosis [91, 92].

In 2013 in Russia operations on the brachiocephalic arteries were the most common vascular surgery. Their number grows from year to year [27]. The results of all the three types of surgical intervention performed in 2013 for carotid artery atherosclerosis are shown in Table 8 [27].

The analysis of numerous native and foreign publications allows formulating indications for CS:

restenosis after previously performed CEE [14];

contralateral cranial nerve paresis after a previous surgery on the neck organs [14, 18];

post-radiation condition of the neck organs [14, 93];

high location of the CCA bifurcation (at C2-3) [14, 18, 94];

inflammatory and tumor-like lumps in the neck [14];

high-risk perioperative patients and patients with severe comorbidity [14, 94-98];

patients with stenosis combined with aneurysms and arteriovenous malformations of the cerebral arteries [99];

cases of multifocal atherosclerotic lesions with a necessity of single-step operations [100];

patients with high risk for cerebral ischemia during carotid clamping (presence of carotid artery occlusion individually and depend on a number of factors: a type and extent of an atherosclerotic plaque; a degree of stenosis of the operated and contralateral internal carotid artery, age and the presence of comorbidity, features of local and vascular anatomy, etc.

The choice of the type of surgical intervention should be decided by a multidisciplinary team of doctors (a vascular surgeon, a neurosurgeon, an X-ray endovascular surgeon, an anesthesiologist-resuscitation specialist, a neurologist, a cardiologist) who can assess the risk of intervention and appropriateness of its performance.

Brain revascularization surgery - carotid endarterectomy and carotid stenting - should be seen not only as a method of prevention of ischemic stroke, but also as a method of treatment of chronic cerebral ischemia.

Study Funding and Conflicts of Interest. This study was not supported by any financial sources and there is no topic specific conflicts of interest related to the authors of this study.

\section{References}

1. Suslina Z.A., Chechetkin A.O., Kuntsevich G.I., Krotenkova M.V. Application algorithm of carotid angio-imaging techniques. Nervnye bolezni 2013: 1: 6-9.

2. Akhmedov A.D., Usachev D.Yu., Lukshin V.A., Shmigel'skiy A.V., Beliaev A.Yu., Sosnin A.D. Carotid endarterectomy in patients with high surgical risk. Voprosy neyrokhirurgii im. N.N. Burdenko 2013; 77(4): 36-42.

3. Kadykov A.S., Shakhparonova N.V. Early rehabilitation of patients after stroke. The role of drug therapy. Nervnye bolezni 2014: 1: 22-25. 
4. Kim A.S., Johnston S.C. Temporal and geographic trends in global stroke epidemic. Stroke 2013; 44(6 Suppl 1): S123-S125, http://dx.doi.org/10.1161/STROKEAHA.111.000067.

5. Lloyd-Jones D., Adams R.J., Brown T.M., Carnethon M., Dai S., De Simone G., Ferguson T.B., Ford E., Furie K., Gillespie C., Go A., Greenlund K., Haase N., Hailpern S., Ho P.M., Howard V., Kissela B., Kittner S., Lackland D., Lisabeth L., Marelli A., McDermott M.M., Meigs J., Mozaffarian D., Mussolino M., Nichol G., Roger V.L., Rosamond W., Sacco R., Sorlie P., Stafford R., Thom T., Wasserthiel-Smoller S., Wong N.D., Wylie-Rosett J.; American Heart Association Statistics Committee and Stroke Statistics Subcommittee. Executive summary: heart disease and stroke statistics - 2010 update: a report from the American Heart Association. Circulation 2010; 121(7): 948-954, http://dx.doi.org/10.1161/CIRCULATIONAHA.109.192666.

6. Domashenko M.A., Tanashyan M.M. Vasoactive therapy of chronic cerebrovascular diseases. Nervnye bolezni 2012; 2: 35-38.

7. Tanashyan M.M., Lagoda O.V., Fedin P.A., Konovalov R.N., Rodionova Yu.V. Modern approaches to the treatment of patients with chronic cerebrovascular diseases. Nervnye bolezni 2010; 4: 19-22.

8. Maslova N.N., Alfimova G.Yu. Dynamics of stroke clinicepidemiologic characteristics in Smolensk region. Zhurnal nevrologii i psikhiatrii im. S.S. Korsakova. Insul't 2009; 10(part 2): 60-64.

9. Feigin V.L., Barker-Collo S., Krishnamurthi R., Theadom A., Starkey N. Epidemiology of ischaemic stroke and traumatic brain injury. Best Practi Res Clin Anaesthesiol 2010; 42(4): 485-494, http://dx.doi.org/10.1016/j.bpa.2010.10.006.

10. Kernan W.N., Ovbiagele B., Black H.R., Bravata D.M., Chimowitz M.I., Ezekowitz M.D., Fang M.C., Fisher M., Furie K.L., Heck D.V., Johnston S.C., Kasner S.E., Kittner S.J., Mitchell P.H., Rich M.W., Richardson D., Schwamm L.H., Wilson J.A.; American Heart Association Stroke Council, Council on Cardiovascular and Stroke Nursing, Council on Clinical Cardiology, and Council on Peripheral Vascular Disease. Guidelines for the prevention of stroke in patients with stroke and transient ischemic attack: a guideline for healthcare professionals from the American Heart Association/American Stroke Association. Stroke 2014; 45(7): 2160-2236, http://dx.doi.org/10.1161/STR.0000000000000024.

11. Androfagina O.V., Strelnikova I.A., Chernyh E.F. Clinicalepidemiological analysis of acute cerebrovascular disease according to the hospital register data of Samara Regional Vascular Centre. Meditsinskiy al'manakh 2011; 1: 48-50.

12. Kim Y.D., Choi H.Y., Cho H.J., Cha M.J., Nam C.M., Han S.W., Nam H.S., Heo J.H. Increasing frequency and burden of cerebral artery atherosclerosis in Korean stroke patients. Yonsei Med J 2010; 51(3): 318-325, http://dx.doi.org/10.3349/ ymj.2010.51.3.318.

13. Klinicheskaya angiologiya [Clinical Angiology]. Vol. 1. Pokrovsky A.V. (editor). Moscow: "Izdatel'stvo "Meditsina”; 2004; $808 \mathrm{p}$.

14. National recommendations for the management of patients with the diseases of brachiocephalic arteries. Angiol Sosud Khir 2013; Suppl 19(2). URL: http://webmed.irkutsk.ru/doc/pdf/ brachiocephalic.pdf.

15. De Bakey M.E., Crawford E.S., Cooley D.A., Morris J.C. Jr. Surgical considerations of occlusive disease of innominate, carotid, subclavian and vertebral arteries. Ann Surg 1959; 149(5): 690-710, http://dx.doi.org/10.1097/00000658-195905000-00010.

16. Raithel D., Kasprzak P. Angioscopy after carotid endarterectomy. Annales Chirurgicales et Gynecologie 1992; 81: 192-195.

17. Sidorov A.A., Kokov L.S., Belo'artsev D.F., Tsygankov
V.N., Shutikhina I.V., Goncharov A.I. Comparison of remote results outcomes of stenting and eversion endarterectomy from internal carotid arteries. Angiol Sosud Khir 2012; 18(2): 124-129.

18. Klinicheskie rekomendatsii po vedeniyu patsientov $s$ sosudistoy arterial'noy patologiey (Rossiyskiy soglasitel'nyy dokument). Chast' 3. Ekstrakranial'nye (brakhiotsefal'nye) arterii [Clinical recommendations for the management of patients with vascular arterial pathology (Russian conciliatory document). Part 3. Extracranial (brachiocephal) arteries]. Moscow: NTsSSKh im. A.N. Bakuleva RAMN 2012; 130 p. URL: http://racvs.ru/custom/ files/clinic/patology2012.pdf.

19. Gavrilenko A.V., Ivanov V.A., Piven A.V., Kuklin A.V., Kravchenko A.A., Miklashevich E.R., Abugov S.A. Outcomes of carotid endarterectomy and stenting in patients with carotid artery stenosis. Angiol Sosud Khir 2012; 18(1): 105-113.

20. Kazanchyan P.O., Lar'kov R.N., Esayan A.V., Sotnikov P.G., Kozorin M.G. Efficacy of internal carotid artery reconstruction in patients with prior ischemic stroke. Kardiologiia $i$ serdechno-sosudistaia khirurgiia 2012; 3: 48-51.

21. Babu M.A., Meissner I., Meyer F.B. The durability of carotid endarterectomy: long-term results for restenosis and stroke. Neurosurgery 2013; 72(5): 835-838, http://dx.doi.org/10.1227/ NEU.0b013e31828a7e30.

22. Kamenskiy A.V., Mactaggart J.N., Pipinos I.I., Gupta P.K., Dzenis Y.A. Hemodynamically motivated choice of patch angioplasty for the performance of carotid endarterectomy. Ann Biomed Eng 2013; 41(2): 263-278, http://dx.doi.org/10.1007/ s10439-012-0640-2.

23. Telepneva M.L., Ivanov L.N., Chebotar E.V., Naumov S.V., Katynov V.V., Shultz A.A., Chatkin D.G. Approach to surgical treatment of high risk patients with atherosclerotic disease of carotid arteries. Meditsinskiy al'manakh 2015; 3: 57-60.

24. Bekbosynov A.Zh. The surgical prevention of acute disturbance of brain circulation at patients with a stenosis of an internal carotid. Tikhookeanskiy meditsinskiy zhurnal 2013; 4: 106-107.

25. Gavrilenko A.V., Kuklin A.V., Kravchenko A.A., Piven A.V. Efficiency of carotid endarterectomy in elderly and gerontic patients who suffered ischemic stroke. Annaly khirurgii 2012; 1: 42-47.

26. Ballotta E., Toniato A., Da Roit A., Lorenzetti R., Piatto G., Baracchini C. Carotid endarterectomy for asymptomatic carotid stenosis in the very elderly. J Vasc Surg 2015; 61(2): 382-388, http://dx.doi.org/10.1016/j.jvs.2014.07.090.

27. Pokrovskiy A.V., Gontarenko V.N. Sostoyanie sosudistoy khirurgii v Rossii v 2013 godu [Status of vascular surgery in Russia in 2013]. Moscow; 2014.

28. Eghbalieh S.D., Chowdhary P., Muto A., Ziegler K.R., Kudo F.A., Pimiento J.M., Mirmehdi I., Model L.S., Kondo Y., Nishibe T., Dardik A. Age-related neointimal hyperplasia is associated with monocyte infiltration after balloon angioplasty. J Gerontol A Biol Sci Med Sci 2012; 67(2): 109-117, http://dx.doi. org/10.1093/gerona/glr190.

29. Reinert M., Mono M.L., Kuhlen D., Mariani L., Barth A., Beck J., Andres R.H., Gralla J., Wymann R., Schmidt J., Kauert C., Schroth G., Arnold M., Mattle H.P., Raabe A., Fischer U. Restenosis after microsurgical non-patch carotid endarterectomy in 586 patients. Acta Neurochir (Wien) 2012; 154(3): 423-431, http://dx.doi.org/10.1007/s00701-011-1233-9.

30. Archie J.P. Jr. Prevention of early restenosis and thrombosis-occlusion after carotid endarterectomy by saphenous vein patch angioplasty. Stroke 1986; 17(5): 901-905, http://dx.doi. org/10.1161/01.str.17.5.901.

31. van Lammeren G.W., Peeters W., de Vries J.P., de Kleijn D.P., De Borst G.J., Pasterkamp G., Moll F.L. Restenosis after carotid surgery: the importance of clinical presentation and 
preoperative timing. Stroke 2011; 42(4): 965-471, http://dx.doi. org/10.1161/STROKEAHA.110.603746.

32. Furie K.L., Kasner S.E., Adams R.J., Albers G.W., Bush R.L., Fagan S.C., Halperin J.L., Johnston S.C., Katzan I., Kernan W.N., Mitchell P.H., Ovbiagele B., Palesch Y.Y., Sacco R.L., Schwamm L.H., Wassertheil-Smoller S., Turan T.N., Wentworth D.; American Heart Association Stroke Council, Council on Cardiovascular Nursing, Council on Clinical Cardiology, and Interdisciplinary Council on Quality of Care and Outcomes Research. Guidelines for the prevention of stroke in patients with stroke or transient ischemic attack: a guideline for healthcare professionals from the American Heart Association/American Stroke Association. Stroke 2011; 42(1): 227-277, http://dx.doi. org/10.1161/STR.0b013e3181f7d043.

33. Hertzer N.R., Beven E.G., O'Hara P.J., Krajewski L.P. Three-year results for 801 patients and 917 operations. Ann Surg 1987; 206(5): 628-635, http://dx.doi.org/10.1097/00000658198711000-00013.

34. Ranaboldo C.J., D'Sa A.A., Bell P.R., Chant A.D., Perry P.M. Randomized controlled trial of patch angioplasty for carotid endarterectomy. The Joint Vascular Research Group. Br J Surg 1993; 80(12): 1528-1530, http://dx.doi.org/10.1002/ bjs. 1800801211 .

35. AbuRahma A.F., Khan J.H., Robinson P.A., Saiedy S., Short Y.S., Boland J.P. Prospective randomized trial of carotid endarterectomy with primary closure and patch angioplasty with saphenous vein jugular vein, and polytetrafluoroethylene: perioperative (30-day) results. J Vasc Surg 1996; 24(6): 998-1006, http://dx.doi.org/10.1016/s0741-5214(96)70045-9.

36. Katras T., Baltazar U., Rush D.S., Sutterfield W.C., Harvill L.M., Stanton P.E. Jr. Durability of eversion carotid endarterectomy: comparison with primary closure and carotid patch angioplasty. J Vasc Surg 2001; 34(3): 453-458, http://dx.doi. org/10.1067/mva.2001.117885.

37. Ali T., Sabharwal T., Dourado R.A., Padayachee T.S., Hunt T., Burnand K.G. Sequential cohort study of Dacron patch closure following carotid endarterectomy. Br J Surg 2005; 92(3): 316-321, http://dx.doi.org/10.1002/bjs.4808.

38. Rockman C.B., Halm E.A., Wang J.J., Chassin M.R., Tuhrim S., Formisano P., Riles T.S. Primary closure of the carotid artery is associated with poorer outcomes during carotid endarterectomy. J Vasc Surg 2005; 42(5): 870-877, http://dx.doi. org/10.1016/j.jvs.2005.07.043.

39. Verhoeven B.A., Pasterkamp G., de Vries J.P., Ackerstaff R.G., de Kleijn D., Eikelboom B.C., Moll F.L. Closure of the arteriotomy after carotid endarterectomy: patch type is related to intraoperative microemboli and restenosis rate. J Vasc Surg 2005; 42(6): 1082-1088, http://dx.doi.org/10.1016/j.jvs.2005.08.011.

40. Mannheim D., Weller B., Vahadim E., Karmeli R. Carotid endarterectomy with a polyurethane patch versus primary closure: a prospective randomized study. J Vasc Surg 2005; 41: 403-408, http://dx.doi.org/10.1016/j.jvs.2004.11.036.

41. Hertzer N.R., Mascha E.J. A personal experience with coronary artery bypass grafting carotid patching, and other factors influencing the outcome of carotid endarterectomy. $J$ Vasc Surg 2006; 43(5): 959-968, http://dx.doi.org/10.1016/j.jvs.2005.12.060.

42. Fokin A.A., Kuvatov A.V. Long-term outcomes of carotid reconstructions with patch angioplasty. Vestnik eksperimental'noy i klinicheskoy khirurgii 2013; 6(2): 239-243.

43. Fokin A.A., Kuvatov A.V., Rodnyanskiy D.V., Degtyarov M.S. Short-term outcomes of carotid endarterectomies using different types of patch materials. Vestnik eksperimental'noy $i$ klinicheskoy khirurgii 2001; 4(1): 140-142.

44. Rerkasem K., Rothwell P.M. Patches of different types for carotid patch angioplasty. Cochrane Database Syst Rev 2010; 3:
CD000071, http://dx.doi.org/10.1002/14651858.CD000071.pub3.

45. Archie J.P. A fifteen-year experience with carotid endarterectomy after a formal operative protocol requiring highly frequent patch angioplasty. J Vasc Surg 2000; 31(4): 724-735, http://dx.doi.org/10.1067/mva.2000.104591.

46. Jacobowitz G.R., Kalish J.A., Lee A.M., Adelman M.A., Riles T.S., Landis R. Long-term follow-up of saphenous vein, internal jugular vein, and knitted Dacron patches for carotid artery endarterectomy. Ann Vascular Surg 2001; 15(3): 281-287, http:// dx.doi.org/10.1007/s100160010086.

47. Grego F., Antonello M., Lepidi S., Bonvini S., Deriu G.P. Prospective randomized study of external jugular vein patch versus polytetrafluoroethylene patch during carotid endarterectomy: perioperative and long-term results. J Vasc Surg 2003; 38(6): 1232-1240, http://dx.doi.org/10.1016/S0741-5214(03)00912-1.

48. Naylor R., Hayes P.D., Payne D.A., Allroggen H., Steel S., Thompson M.M. Randomized trial of vein versus dacron patching during carotid endarterectomy: long-term results. J Vasc Surg 2004; 39(5): 985-993, http://dx.doi.org/10.1016/j.jvs.2004.01.037.

49. AbuRahma A.F., Stone P.A., Elmore M., Flaherty S.K., Armistead L., AbuRahma Z. Prospective randomized trial of ACUSEAL (Gore-Tex) vs Finesse (Hemashield) patching during carotid endarterectomy: long-term outcome. J Vasc Surg 2008; 48(1): 99-103, http://dx.doi.org/10.1016/j.jvs.2008.01.057.

50. Karpenko A.A., Kuzhuget R.A., Starodubtsev V.B., Ignatenko P.V., Kim I.N., Gorbatykh V.N. Immediate and longterm outcomes of carotid bifurcation remodeling. Patologiya krovoobrashcheniya i kardiokhirurgiya 2013; 1: 21-24.

51. Cao P., de Rango P., Zannetti S., Giordano G., Ricci S., Celani M.G. Eversion versus conventional carotid endarterectomy for preventing stroke. Cochrane Database Syst Rev 2001; (1): CD001921, http://dx.doi.org/10.1002/14651858.CD001921.

52. Antonopoulos C.N., Kakisis J.D., Sergentanis T.N., Liapis C.D. Eversion versus conventional carotid endarterectomy: a meta-analysis of randomised and non-randomised studies. Eur J Vasc Endovasc Surg 2011; 42(6): 751-765, http://dx.doi. org/10.1016/j.ejvs.2011.08.012.

53. Demirel S., Attigah N., Bruijnen H., Ringleb P., Eckstein H.H., Fraedrich G., Böckler D. Multicenter experience on eversion versus conventional carotid endarterectomy in symptomatic carotid artery stenosis: observations from the Stent-Protected Angioplasty versus Carotid Endarterectomy (SPACE-1). Stroke 2012; 43(7): 1865-1871, http://dx.doi. org/10.1161/STROKEAHA.111.640102.

54. Srtepetov N.N., Pchelintsev K.E., Ponomarev E.A., Maskin S.S. Modern approach to surgical correction of ischemic damage of brain. Vestnik Volgogradskogo gosudarstvennogo meditsinskogo universiteta 2011; 3: 8-13.

55. Grinberg M.S. Neyrokhirurgiya [Neurosurgery]. Moscow: MEDpress-inform; 2010; 1008 p.

56. Rantner B., Schmidauer C., Knoflach M., Fraedrich G. Very urgent carotid endarterectomy does not increase the procedural risk. Eur J Vasc Endovasc Surg 2015; 49(2): 129-136, http:// dx.doi.org/10.1016/j.ejvs.2014.09.006.

57. Dudanov I.P., Vasil'chenko N.O., Koblov E.S., Azieva A.Z., Sterlin O.V., Berger M.M., Ordynetz S.V. Surgical treatment of carotid arteries stenosis in patients with severe neurological deficit in an acute period of ischemic stroke. Neyrokhirurgiya 2013; 2: $18-24$.

58. Salem M.K., Sayers R.D., Bown M.J., Eveson D.J., Robinson T.G., Naylor A.R. Rapid access carotid endarterectomy can be performed in the hyperacute period without a significant increase in procedural risks. Eur J Vasc Endovasc Surg 2011; 41(2): 222-228, http://dx.doi.org/10.1016/j.ejvs.2010.10.017.

59. Bakoyiannis C., Economopoulos K.P., Georgopoulos S., 
Bastounis E., Papalambros E. Carotid endarterectomy versus carotid angioplasty with or without stenting for treatment of carotid artery stenosis: an updated meta-analysis of randomized controlled trials. Int Angiol 2010; 29(3): 205-215.

60. Capoccia L., Sbarigia E., Speziale F., Toni D. Urgent carotid endarterectomy to prevent recurrence and improve neurologic outcome in mild-to-moderate acute neurologic events. J Vasc Surg 2010; 1: 134-137, http://dx.doi.org/10.1016/j.jvs.2010.09.016.

61. Dudanov I.P., Belinskaya V.G., Vasilchenko N.O., Abdurakhimov Z.Z., Laptev K.V., Koblov Ye.S. The experience of rendering medical assistance to patients with symptomatic stenosis of carotids in the acute period of ischemic stroke. Vestnik novykh meditsinskikh tekhnologiy 2011; 18(4): 206-209.

62. Tsivgoulis G., Krogias C., Georgiadis G.S., Mikulik R., Safouris A., Meves S.H., Voumvourakis K., Haršány M., Staffa R., Papageorgiou S.G., Katsanos A.H., Lazaris A., Mumme A., Lazarides M., Vasdekis S.N. Safety of early endarterectomy in patients with symptomatic carotid artery stenosis: an international multicenter study. Eur J Neurol 2014; 21(10): e1251-e1276, http:// dx.doi.org/10.1111/ene.12461.

63. Koraen-Smith L., Troëng T., Björck M., Kragsterman B., Wahlgren C.M.; Swedish Vascular Registry and the Risk-Stroke Collaboration. Urgent carotid surgery and stenting may be safe after systemic thrombolysis for stroke. Stroke 2014; 45(3): 776780, http://dx.doi.org/10.1161/STROKEAHA.113.003763.

64. Merlini T., Péret M., Lhommet P., Debiais S., Marc G., Godard S., Martinez R., Enon B., Picquet J. Is early surgical revascularization of symptomatic carotid stenoses safe? Ann Vasc Surg 2014; 28(6): 1539-1547, http://dx.doi.org/10.1016/ j.avsg.2014.01.025.

65. de Vries J.P., Vos J.A. Comments regarding 'Carotid endarterectomy within seven days after the neurological index event is safe and effective in stroke prevention'. Eur $J$ Vasc Endovasc Surg 2011; 42(6): 740-741, http://dx.doi.org/10.1016/ j.ejvs.2011.09.002.

66. Strömberg S., Gelin J., Osterberg T., Bergström G.M., Karlström L., Osterberg K.; Swedish Vascular Registry (Swedvasc) Steering Committee. Very urgent carotid endarterectomy confers increased procedural risk. Stroke 2012; 43(5): 1331-1335, http:// dx.doi.org/10.1161/STROKEAHA.111.639344.

67. Rantner B., Kollerits B., Schmidauer C., Willeit J., Thauerer M., Rieger M., Fraedrich G. Carotid endarterectomy within seven days after the neurological index event is safe and effective in stroke prevention. Eur $J$ Vasc Endovasc Surg 2011; 42(6): 732-739, http://dx.doi.org/10.1016/j.ejvs.2011.08.004.

68. Chechulov P.V., Voznyuk I.A., Soroka V.V., Varaksina E.A., Aydaev S.S., Zenin A.V. Carotid endarterectomy is safe and justified at the first days after ischemic stroke. Grudnaya $i$ serdechnososudistaya khirurgiya 2013; 3: 24-29.

69. Popov A.P., Gasparyan M.V., Shakhnazaryan A.M., Kutishcheva N.G. Results of surgical treatment of carotid stenosis in patients in the acute period of the ischemic stroke. Vestnik Natsional'nogo mediko-khirurgicheskogo tsentra im. N.I. Pirogova 2013; 2: 24-28.

70. Barbetta I., Carmo M., Mercandalli G., Lattuada P., Mazzaccaro D., Settembrini A.M., Dallatana R., Settembrini P.G. Outcomes of urgent carotid endarterectomy for stable and unstable acute neurologic deficits. J Vasc Surg 2014 59(2): 440-446, http:// dx.doi.org/10.1016/j.jvs.2013.08.035.

71. Spirin N.N., Malyshev N.N., Lazareva T.E., Kozlova L.V. Influence of carotid endarterectomy on neurological, neuropsychological status and quality of life in patients with obliterating atherosclerosis of carotid arteries. Vestnik Ivanovskoy meditsinskoy akademii 2011; 1: 34-38.

72. Spirin N.N., Malyshev N.N. Jr., Malysheva I.V. Analisis of carotid endarterectomy and estimation of the factors influensing on its results. Kurskiy nauchno-prakticheskiy vestnik "Chelovek $i$ ego zdorov'e" 2011; 1: 105-109.

73. Malyshev N.N., Malyshev N.N. Jr., Kozlova I.V. Longterm results and the rehabilitation of patients after carotid endarterectomy. Angiologiya i sosudistaya khirurgiya 2010; 16(4, Suppl): 248-249.

74. Spirin N.N., Malyshev N.N., Malysheva I.V. The assessment of surgical treatment of chronic cerebral ischemia according to the findigs of neurologic and neuropsychologic examination. Fundamentalnie issledovania 2011; 7: 135-137.

75. Kazanchyan P.O., Lar'kov R.N., Lobakov A.I., Esayan A.V. Carotid endarterectomy at patients after ischaemic stroke. Khirurg 2011; 2: 43-51.

76. lakhno N.N., Fedorova T.S., Damulin I.V., Shcherbiuk A.N., Vinogradov O.A., Lavrent'ev A.V. The effect of carotid endarterectomy on cognitive disturbances in patients with atherosclerotic stenosis of carotid arteries. Zhurnal nevrologii $i$ psikhiatrii im. S.S. Korsakova 2011; 3: 31-37.

77. Spirin N.N., Malyshev N.N., Malysheva I.V. The assessment of prognosis of carotid endarterectomy by clinical-mathematical method. Zhurnal nevrologii i psikhiatrii im. S.S. Korsakova 2012; 6: $40-44$

78. Pyshkina L.I., Kabanov A.A., Tekoeva A.R., Pirtskhalaishvili Z.K., Darvish N.A., Ignatenko A.V. Changes in cognitive functions in patients with occlusive lesions of brachiocephalic arteries after reconstructive surgery on carotid arteries. Zhurnal nevrologii i psikhiatrii im. S.S. Korsakova 2011; 1: 16-20.

79. Bockeria L.A., Aslanidi I.P., Pyshkina L.I., Serguladze T.N., Darvish N.A., Gvetadze I.A., Valieva R.R., Khatagova D.G. Cliniconeurological and cognitive functions after reconstructive surgeries in case of brachiocephalic artery stenosis. Klinicheskaya fiziologiya krovoobrashcheniya 2012; 4: 30-38.

80. Pyshkina L.I., Khatagova D.T., Kabanov A.A., Darvish N.A., Alibekova Zh.M. Surgical prevention of stroke in patients with carotid stenosis. Zhurnal nevrologii i psikhiatrii im. S.S. Korsakova 2014; 3(part 2): 14-19.

81. Wang Q., Zhang M., Huang D., Zhou Y., Qiao T. Effects of carotid endarterectomy on cognitive function in patients with carotid stenosis. Zhonghua Wai Ke Za Zhi 2014; 52(8): 602-609.

82. Paraskevas K.I., Lazaridis C., Andrews C.M., Veith F.J., Giannoukas A.D. Comparison of cognitive function after carotid artery stenting versus carotid endarterectomy. Eur J Vasc Endovasc Surg 2014; 47(3): 221-231, http://dx.doi.org/10.1016/ j.ejvs.2013.11.006.

83. Germano da Paz O., Guillaumon A.T., Lopes T.M., Weiler M., Cendes F., Balthazar M.L. Carotid stenting versus endarterectomy cognitive outcomes. Ann Vasc Surg 2014; 28(4): 893-900, http://dx.doi.org/10.1016/j.avsg.2013.10.010.

84. Giacovelli J.K., Egorova N., Rajeev D., Gelijns A., McKinsey J., Ken K.C. Outcomes of carotid stenting compared with endarterectomy are equivalent in asymptomatic patients and inferior in symptomatic patients. J Vasc Surg 2010; 52(4): 906913, http://dx.doi.org/10.1016/j.jvs.2010.05.010.

85. Timaran C.H., Mantese V.A., Malas M., Brown O.W., Lal B.K., Moore W.S., Voeks J.H., Brott T.G.; CREST Investigators. Differential outcomes of carotid stenting and endarterectomy performed exclusively by vascular surgeons in the Carotid Revascularization Endarterectomy versus Stenting Trial (CREST). $J$ Vasc Surg 2013; 57(2): 303-308, http://dx.doi.org/10.1016/ j.jvs.2012.09.014.

86. Brott T.G., Hobson R.W. 2nd, Howard G., Roubin G.S., Clark W.M., Brooks W., Mackey A., Hill M.D., Leimgruber P.P., Sheffet A.J., Howard V.J., Moore W.S., Voeks J.H., Hopkins L.N., 
Cutlip D.E., Cohen D.J., Popma J.J., Ferguson R.D., Cohen S.N., Blackshear J.L., Silver F.L., Mohr J.P., Lal B.K., Meschia J.F.; CREST Investigators. Stenting versus endarterectomy for treatment of carotid-artery stenosis. N Engl J Med 2010; 363: 1123, http://dx.doi.org/10.1056/NEJMoa0912321.

87. Ederle J., Dobson J., Featherstone R.L., Bonati L.H., van der Worp H.B., de Borst G.J., Lo T.H., Gaines P., Dorman P.J., Macdonald S., Lyrer P.A., Hendriks J.M., McCollum C., Nederkoorn P.J., Brown M.M.; International Carotid Stenting Study investigators. Carotid artery stenting compared with endarterectomy in patients with symptomatic carotid stenosis (International Carotid Stenting Study): an interim analysis of a randomised controlled trial. Lancet 2010; 375: 985997, http://dx.doi.org/10.1016/S0140-6736(10)60239-5.

88. Hopkins L.N., Roubin G.S., Chakhtoura E.Y., Gray W.A., Ferguson R.D., Katzen B.T., Rosenfield K., Goldstein J., Cutlip D.E., Morrish W., Lal B.K., Sheffet A.J., Tom M., Hughes S., Voeks J., Kathir K., Meschia J.F., Hobson R.W. 2nd, Brott T.G. The carotid revascularization endarterectomy versus stenting trial: credentialing of interventionalists and final results of lead-in phase. J Stroke Cerebrovasc Dis 2010; 19(2): 153-162, http://dx.doi.org/10.1016/ j.jstrokecerebrovasdis.2010.01.001.

89. Bonati L.H., Dobson J., Featherstone R.L., Ederle J., van der Worp H.B., de Borst G.J., Mali W.P., Beard J.D., Cleveland T., Engelter S.T., Lyrer P.A., Ford G.A., Dorman P.J., Brown M.M.; International Carotid Stenting Study investigators. Long-term outcomes after stenting versus endarterectomy for treatment of symptomatic carotid stenosis: the International Carotid Stenting Study (ICSS) randomised trial. Lancet 2015; 385(9967): 529-538, http://dx.doi.org/10.1016/S0140-6736(14)61184-3.

90. Kuliha M., Roubec M., Procházka V., Jonszta T., Hrbáč T., Havelka J., Goldírová A., Langová K., Herzig R., Školoudík D. Randomized clinical trial comparing neurological outcomes after carotid endarterectomy or stenting. Br J Surg 2015; 102(3): 194201, http://dx.doi.org/10.1002/bjs.9677.

91. Paraskevas K.I., Mikhailidis D.P., Veith F.J. Are symptomatic patients appropriate candidates for carotid artery stenting? No (at least not at present). Vascular 2010; 18(4): 185188, http://dx.doi.org/10.2310/6670.2010.00027.

92. Yavin D., Roberts D.J., Tso M., Sutherland G.R., Eliasziw M., Wong J.H. Carotid endarterectomy versus stenting: a meta-analysis of randomized trials. Can J Neurol Sci 2011; 38(2): 230-235, http://dx.doi.org/10.1017/s0317167100011380.

93. Frasquet-Carrera M., Tembl J.I., Parkhutik V., GorrizRomero D., Aguilella-Linares C., Ibanez-Julia M.J., Lago A. Carotid angioplasty in stenosis following radiotherapy: a review of 12 cases. Rev Neurol 2013; 56(3): 137-142.

94. Suslin Yu.V., Korymasov E.A. Carotid angioplasty and stenting as an alternative to the carotid endarterectomy in patients with stenotic lesions of carotid arteries. Vestnik eksperimental'noy i klinicheskoy khirurgii 2011; 4(2): 385-391.

95. Skrylev S.I., Shchipakin V.L., Koshcheev A.Yu., Evdokimova T.P., Chechetkin A.O., Sinitsyn I.A., Sermagambetova Zh.N. A differentiated approach to surgical treatment of atherosclerotic bilateral lesions of internal carotid arteries. Nervnye bolezni 2014; 2: 25-28.

96. Déglise S., Dubuis C., Mosimann P., Saucy F., Engelberger S., Hirt L., Michel P., Corpataux J.M. Management of the carotid artery stenosis. Rev Med Suisse 2013; 9(391): 1305-1311.

97. Roffi M., Cremonesi A. Current concepts on the management of concomitant carotid and coronary disease. J Cardiovasc Surg (Torino) 2013; 54(1): 47-54.

98. Xu J., Wang J., Li B.M., Li S., Cao X.Y., Liu X.F. Risk factors in carotid angioplasty and stenting for extracranial carotid stenosis of elderly patients. Zhonghua Wai Ke Za Zhi 2012; 50(6): 534-538.

99. Shcheglov V.I., Shcheglov D.V., Konotopchik S.V., Sviridyuk O.E. Experience of stenting of brachiocephalic arteries. Endovaskulyarnaya neyrorentgenokhirurgiya 2013; 2: 44-47.

100. Shevchenko Y.L., Kuznetsov A.N., Kucherenko S.S., Batrashov V.A., Bolomatov N.V. Clinical safety of open and endovascular interventions on carotid arteries. Vestnik Natsional'nogo mediko-khirurgicheskogo tsentra im. N.I. Pirogova 2012; 7(4): 11-16. 